\title{
IODP Expedition 338: NanTroSEIZE Stage 3: NanTroSEIZE plate boundary deep riser 2
}

\author{
G. F. Moore ${ }^{1}$, K. Kanagawa ${ }^{2}$, M. Strasser ${ }^{3}$, B. Dugan ${ }^{4}$, L. Maeda ${ }^{5}$, S. Toczko ${ }^{5}$, and \\ the IODP Expedition 338 Scientific Party \\ ${ }^{1}$ Department of Geology and Geophysics, University of Hawaii, 1680 East-West Rd., Honolulu, HI 96822, USA \\ ${ }^{2}$ Department of Earth Sciences, Chiba University, 1-33 Yayoi-cho, Inage-Ku, Chiba 263-8522, Japan \\ ${ }^{3}$ Geological Institute, ETH Zürich, Sonneggstrasse 5, 8092 Zürich, Switzerland \\ ${ }^{4}$ Department of Earth Sciences, Rice University, 6100 Main Street, MS-126, Houston, TX 77005, USA \\ ${ }^{5}$ Center for Deep Earth Exploration, Japan Agency for Marine-Earth Science and Technology, \\ 3173-25 Showa-machi, Kanazawa-ku, Yokohama 236-0001, Japan
}

Correspondence to: G. F. Moore (gmoore@ hawaii.edu)

Received: 21 August 2013 - Revised: 4 November 2013 - Accepted: 26 November 2013 - Published: 7 January 2014

\begin{abstract}
The Nankai Trough Seismogenic Zone Experiment (NanTroSEIZE) is designed to investigate fault mechanics and seismogenesis along a subduction megathrust, with objectives that include characterizing fault slip, strain accumulation, fault and wall rock composition, fault architecture, and state variables throughout an active plate boundary system. Integrated Ocean Drilling Program (IODP) Expedition 338 was planned to extend and case riser Hole C0002F from 856 to 3600 meters below the seafloor (m b.s.f.). Riser operations extended the hole to $2005.5 \mathrm{~m}$ b.s.f., collecting logging-while-drilling (LWD) and measurement-while-drilling, mud gas, and cuttings data. Results reveal two lithologic units within the inner wedge of the accretionary prism that are separated by a prominent fault zone at $\sim 1640 \mathrm{~m}$ b.s.f. Due to damage to the riser during unfavorable winds and strong currents, riser operations were suspended, and Hole C0002F left for re-entry during future riser drilling operations.

Contingency riserless operations included coring at the forearc basin site (C0002) and at two slope basin sites (C0021 and C0022), and LWD at one input site (C0012) and at three slope basin sites (C0018, C0021 and C0022). Cores and logs from these sites comprehensively characterize the alteration stage of the oceanic basement input to the subduction zone, the early stage of Kumano Basin evolution, gas hydrates in the forearc basin, and recent activity of the shallow megasplay fault zone system and associated submarine landslides.
\end{abstract}

\section{Introduction}

Subduction zones generate Earth's most destructive earthquakes, but much of what we thought we knew about great earthquakes, and the tsunamis they generate, was turned upside down by the 2004 Sumatra and 2011 Tohoku events. To better understand seismogenesis and rupture propagation along subduction plate boundary faults, the Integrated Ocean Drilling Program (IODP) implemented drilling as part of the Nankai Trough Seismogenic Zone Experiment (NanTroSEIZE) along a transect offshore of the Kii Peninsula, Honshu, Japan (Tobin and Kinoshita, 2006; Figs. 1, 2).
The Nankai Trough is formed by subduction of the Philippine Sea Plate to the northwest beneath the Eurasian Plate at a rate of $\sim 4.1-6.5 \mathrm{~cm} \mathrm{yr}^{-1}$ (Fig. 1) (Seno et al., 1993; Miyazaki and Heki, 2001), and Shikoku Basin oceanic plate sediment is actively accreting at the deformation front. In the seaward portion of the Kumano forearc basin, the genic zone lies $<6000 \mathrm{~m}$ below sea floor (mb.s.f.) (Nakanishi et al., 2002). The Nankai Trough region has a $1300 \mathrm{yr}$ historical record of recurring great earthquakes that are typically tsunamigenic, including the 1944 Tonankai $M_{\mathrm{w}} 8.2$ and 1946 Nankai $M_{\mathrm{w}} 8.3$ earthquakes (Fig. 1; Ando, 1975; Hori et al., 2004, Baba et al., 2006). 


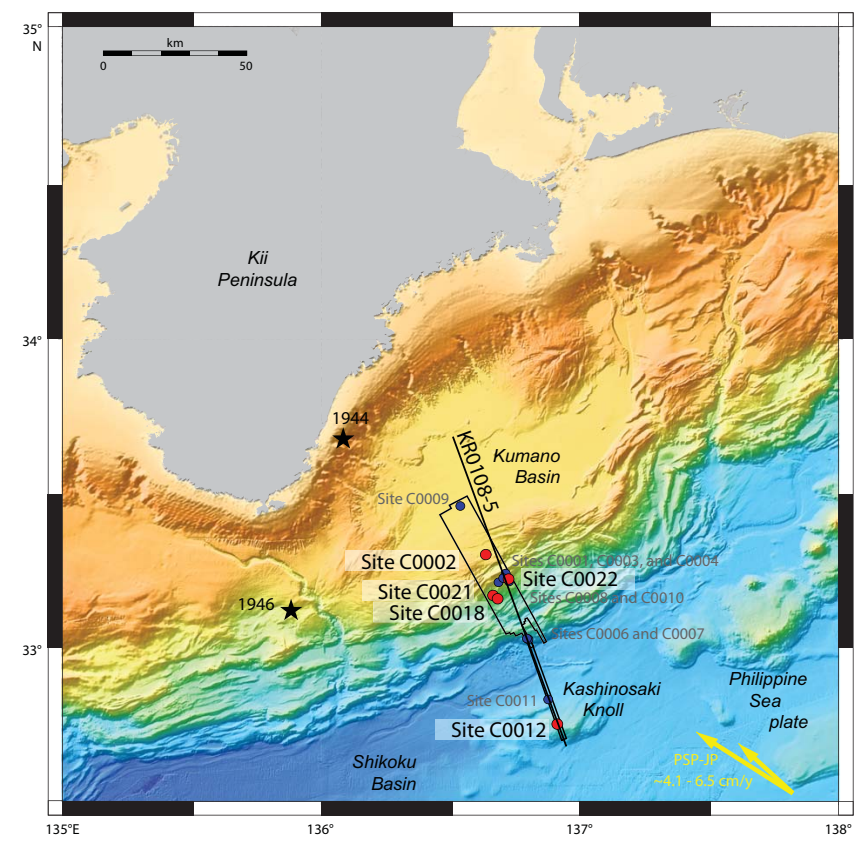

Figure 1. Map of the NanTroSEIZE region showing all Stage 1, 2, and 3 drill sites. Red $=$ Expedition 338 sites, blue $=$ NanTroSEIZE Stage 1 and 2 sites. Black outline = region with 3-D seismic data, yellow arrows = estimated far-field vectors for motion of Philippine Sea Plate (PSP) with respect to Japan (JP) (Seno et al., 1993; Heki, 2007). Stars $=$ epicenter locations of 1944 and 1946 tsunamigenic earthquakes. Black line $=$ KR0108-5 seismic reflection line shown in Fig. 2.

Along the Nankai margin, high-resolution seismic reflection profiles across the outer wedge of the accretionary prism (including $\mathrm{a} \sim 11 \mathrm{~km} \times 55 \mathrm{~km} 3-\mathrm{D}$ seismic reflection volume; Moore et al., 2009), clearly document a large out-ofsequence-thrust fault system (the megasplay fault; Park et al., 2002; Fig. 2) that branches from the plate boundary close to the updip limit of inferred coseismic rupture in the Tonankai earthquake (Fig. 1). The megasplay system is active and it may accommodate an appreciable component of plate boundary motion, but the partitioning of strain between the décollement zone and the megasplay system (Fig. 2) and the mechanics of fault slip as a function of depth and time on the megasplay remain poorly understood. The main objectives of the NanTroSEIZE project include documenting the role of the megasplay fault in accommodating seismic and interseismic plate motion and characterizing its mechanical and hydrologic behavior.

During stages 1 and 2 of NanTroSEIZE (IODP Expeditions $314,315,316,319,322,332$, and 333), eight riserless drilling sites and one riser drilling site targeted the incoming Philippine Sea Plate, the frontal thrust region, the midslope megasplay fault region, and the Kumano forearc basin (Figs. 1, 2; Kinoshita et al., 2009; Saffer et al., 2010; Saito et al., 2010; Kopf et al., 2011; Henry et al., 2012).
NanTroSEIZE Stage 3 began with IODP Expedition 326 , during which casing was installed in Hole $\mathrm{C} 0002 \mathrm{~F}$ to $860 \mathrm{~m}$ b.s.f. (Expedition 326 Scientists, 2011). Although IODP Expedition 338 drilling was planned only to deepen Hole $\mathrm{C} 0002 \mathrm{~F}$, we also conducted riserless coring and logging at Site C0002 and four additional sites (Table 1).

Site C0002 is planned to access the plate interface fault system where it is believed to be capable of seismogenic locking and slip, and to have slipped coseismically in the Tonankai earthquake (Ichinose et al., 2003). This fault system also includes the region where a cluster of very low frequency (VLF) seismic events occurred in 2004-2005 (Ito and Obara, 2006) and the first tectonic tremor recorded in an accretionary prism setting was found (Obana and Kodaira, 2009). To access, sample, and monitor these deeper zones, Hole C0002F will be deepened in 2013-2015, with the ultimate goals of penetrating the megasplay fault and installing a long-term observatory.

In this paper we present the initial results of logging, cuttings, mud gas and coring during Expedition 338. We characterize the petrophysical properties and lithological/structural associations determined from our log, cuttings and core data.

\section{Scientific objectives of Expedition 338}

The fundamental objectives of Expedition 338 are:

- To sample the forearc basin sediment and gas hydrate zone, the Kumano forearc basin - accretionary prism unconformity, and the upper portion of the inner wedge to (1) determine the composition, age, stratigraphy, and internal style of deformation; (2) characterize the gas hydrate zone in the forearc basin; (3) reconstruct thermal, diagenetic, and metamorphic history; (4) investigate the mechanical state and behavior of the formation; and (5) characterize the overall structural evolution of the accretionary prism.

- To characterize the sedimentary section and mass transport deposits (MTDs) in a slope basin seaward of the megasplay fault at sites C0018 and C0021 (Figs. 3, 4) to understand the nature of MTDs and their sliding dynamics and tsunamigenic potential.

- To target the uppermost $400 \mathrm{~m}$ b.s.f. near the projected fault tip of the megasplay fault. The seismic reflection data had previously identified this region as the tip of the megasplay fault that emplaced the block drilled at Site C0004 over slope basin strata (Fig. 5; Moore et al., 2009). This megasplay fault is thought to coincide with the outermost rupture area of the Tonankai earthquake, and its slip was likely in part responsible for the associated devastating tsunami (Park et al., 2002; Moore et al., 2007).

- To characterize the sedimentary section and the upper portion of the oceanic crust (Site C0012) in the Shikoku 


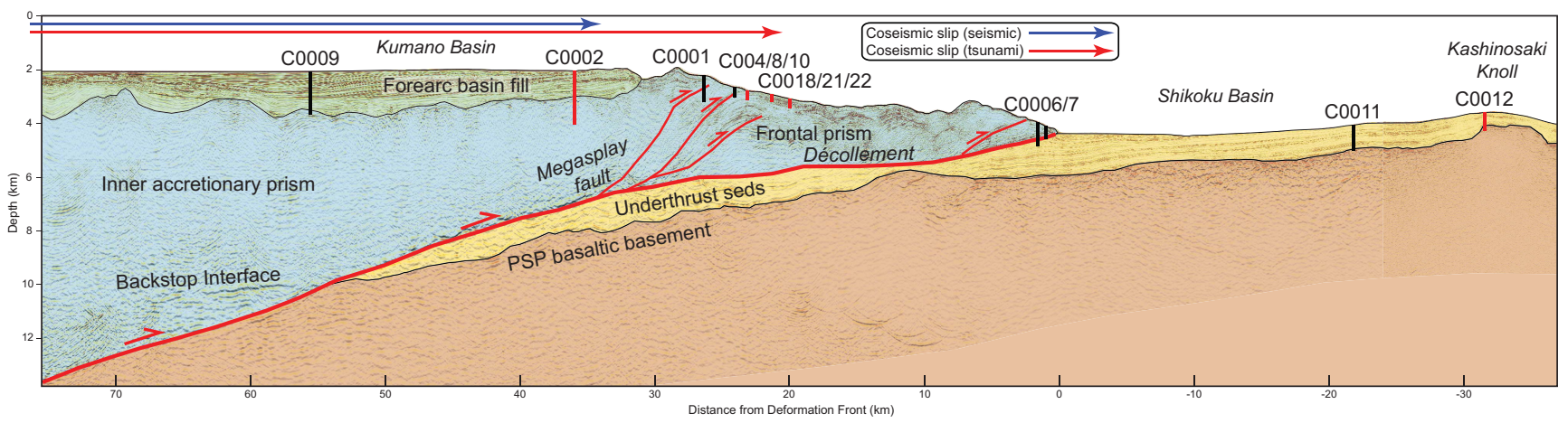

Figure 2. Regional 2-D seismic line showing Expedition 338 sites (red) in relation to NanTroSEIZE Stage 1 and 2 sites (black). PSP = Philippine Sea Plate. Lines at top with arrows indicate seaward distribution of coseismic slips 1944 and 1946 earthquakes estimated from tsunami inversion (red; Tanioka and Satake, 2001) and seismic waveform inversion (blue; Ichinose et al., 2003; Kikuchi et al., 2003). Location shown in Fig. 1. Modified from Park et al. (2002, 2008) and Nakanishi et al. (2008).

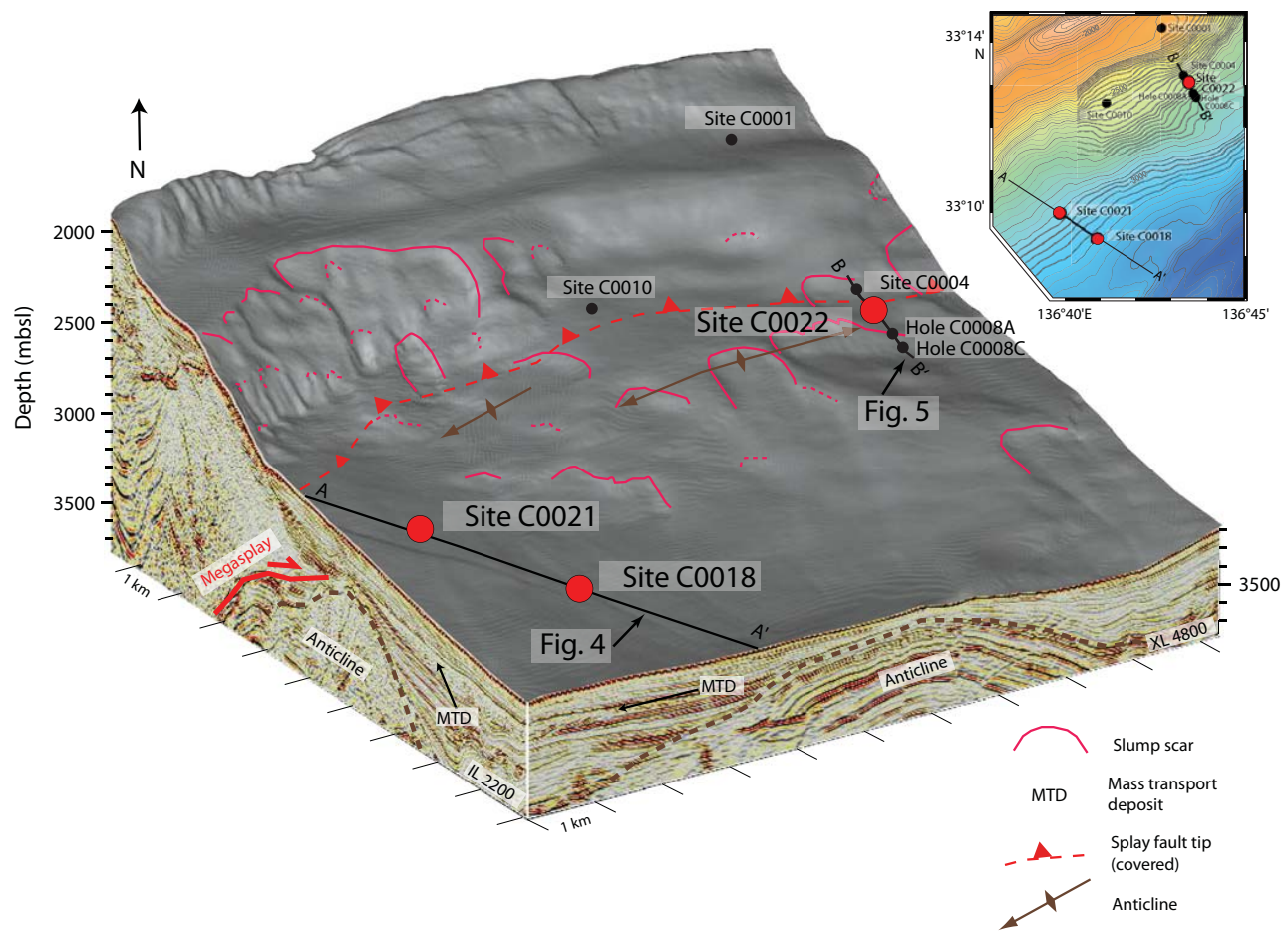

Figure 3. Detailed surface morphology and structure of the slope basin at the footwall of the splay fault (Strasser et al., 2011) showing Expedition 338 sites (red) in relation to NanTroSEIZE Stage 1 and 2 sites (black). Solid black lines = locations of seismic lines A-A' and B-B' in Figs. 4 and 5, respectively. MTD = mass transport deposit, IL = in-line, $\mathrm{XL}=$ cross-line.

Basin on the crest of Kashinosaki Knoll (Ike et al., 2008) on the subducting Philippine Sea Plate (Figs. 1, 2) to understand (1) how compressional velocity relates to compaction state and fluid sources; and (2) how igneous basement structures relate to the alteration state.

\subsection{Site $\mathrm{C} 0002$ in Kumano forearc basin}

Five lithologic units (I-V), based on cuttings and cores, are identified at Site C0002 (Fig. 6). In the Kumano forearc basin sediment (lithologic units II and III) in holes C0002J, $\mathrm{C} 0002 \mathrm{~K}$, and $\mathrm{C} 0002 \mathrm{~L}$, bedding is subhorizontal to gently dipping. At the base of lithologic Unit III, however, bedding is intensely disrupted and boudinaged. Vein structures (Ogawa, 1980) were observed in cores and cuttings exclusively from Unit III in holes C0002F and C0002J.

The lithologic Unit III/IV boundary is defined at different depths in holes $\mathrm{C} 0002 \mathrm{~F}$ and $\mathrm{C} 0002 \mathrm{~J}$ as a result of mixing of cuttings over an interval of as much as $\sim 100 \mathrm{~m}$ in 


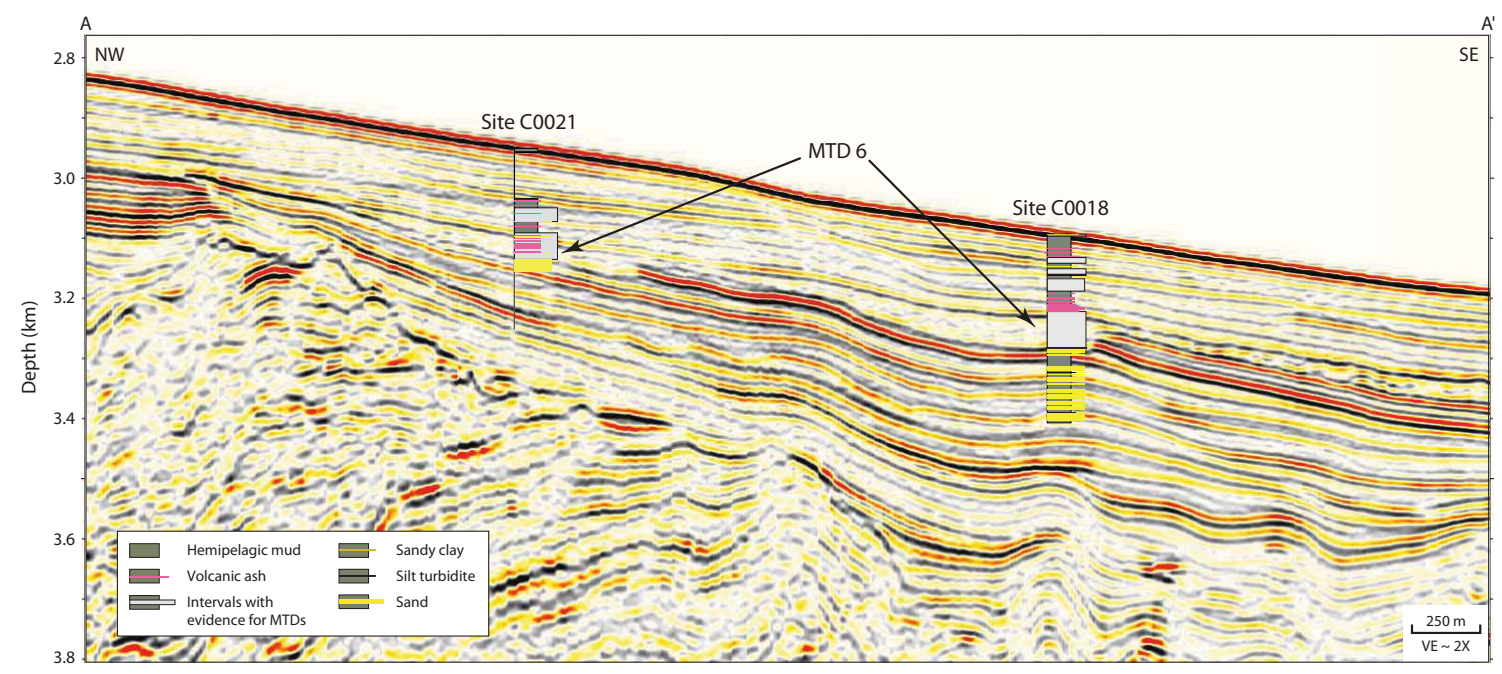

Figure 4. Lithostratigraphic summary columns of sites C0018 and C0021 overlain on an arbitrary seismic line A-A' linking the two sites. Seismic line location shown in Fig. 3. MTD = mass transport deposit, VE = vertical exaggeration.

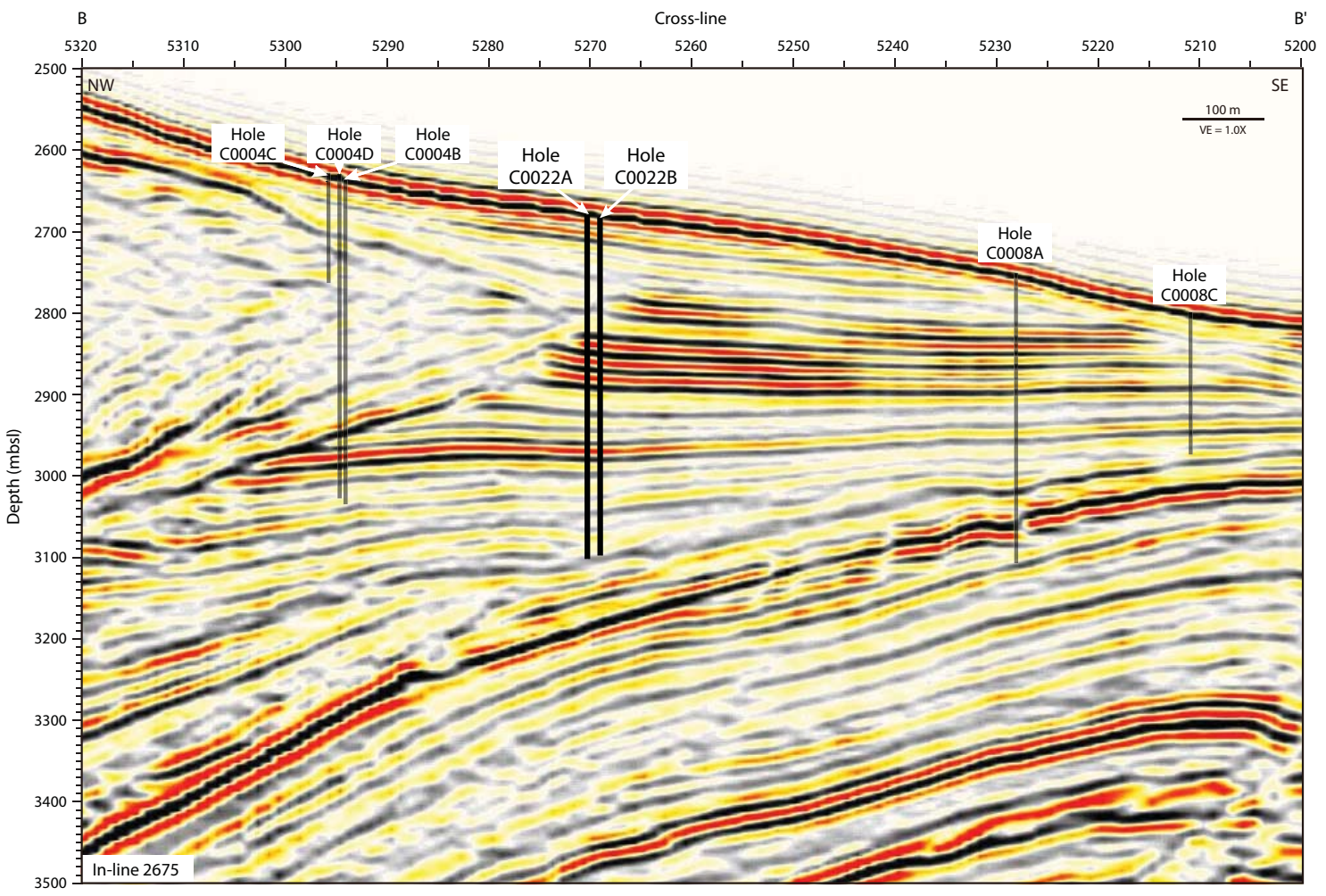

Figure 5. In-line $2675\left(\mathrm{~B}-\mathrm{B}^{\prime}\right)$ extracted from 3-D seismic volume, showing sites C0004, C0008, and C0022 (Moore et al., 2009). Location shown in Fig. 3. VE = vertical exaggeration.

C0002F, resulting in uncertainty of that depth magnitude (see Strasser et al., 2014a for a detailed discussion of reaming while drilling and the mixing of cuttings). The lithologic Unit III/IV boundary was cored at 926.7 m b.s.f. in Hole C0002J (Fig. 6), where we interpret it as an erosional unconformity.
In the upper accretionary prism (lithologic Unit IV, holes $\mathrm{C} 0002 \mathrm{H}$ and $\mathrm{C0002J}$ ), bedding is subhorizontal to steeply dipping toward the south or north. Up to $10 \%$ of the cuttings in the interval $1550.5-1675.5 \mathrm{~m}$ b.s.f. exhibit slickenlined surfaces. This interval correlates with the high fracture 
Table 1. Expedition 338 coring summary.

\begin{tabular}{|c|c|c|c|c|c|c|c|c|c|c|}
\hline Hole & Latitude & Longitude & $\begin{array}{l}\text { Water } \\
\text { depth (m b.s.l.) }\end{array}$ & $\begin{array}{l}\text { Cores } \\
(N)\end{array}$ & $\begin{array}{l}\text { Interval } \\
\text { cored }(\mathrm{m})\end{array}$ & $\begin{array}{l}\text { Core } \\
\text { recovered } \\
(\mathrm{m})\end{array}$ & $\begin{array}{l}\text { Recovery } \\
(\%)\end{array}$ & $\begin{array}{l}\text { Drilled } \\
\text { interval }(\mathrm{m})\end{array}$ & $\begin{array}{l}\text { Total } \\
\text { penetration } \\
\text { (m) }\end{array}$ & $\begin{array}{l}\text { Time on } \\
\text { site (days) }\end{array}$ \\
\hline \multicolumn{11}{|l|}{$338-$} \\
\hline $\mathrm{C} 0002 \mathrm{~F}$ & $33^{\circ} 18.0507^{\prime} \mathrm{N}$ & $136^{\circ} 38.2029^{\prime} \mathrm{E}$ & 1939.00 & 0 & LWD/MWD & - & - & $842-2005.5$ & 2005.5 & 6.2 \\
\hline $\mathrm{C} 0002 \mathrm{H}$ & $33^{\circ} 18.0252^{\prime} \mathrm{N}$ & $136^{\circ} 38.2152^{\prime} \mathrm{E}$ & 1936.50 & 2 & 19.0 & 3.91 & 20.6 & $0-1120.0$ & 1120.0 & 3.5 \\
\hline C0002I & $33^{\circ} 18.0362^{\prime} \mathrm{N}$ & $136^{\circ} 38.2077^{\prime} \mathrm{E}$ & 1936.00 & 0 & - & - & - & _- & 1360.5 & 5 \\
\hline $\mathrm{C} 0002 \mathrm{~J}$ & $33^{\circ} 18.0173^{\prime} \mathrm{N}$ & $136^{\circ} 38.2312^{\prime} \mathrm{E}$ & 1937.50 & 7 & 38.0 & 22.19 & 58.4 & $0-940.0$ & 940.0 & 3.5 \\
\hline $\mathrm{C} 0002 \mathrm{~K}$ & $33^{\circ} 18.0063^{\prime} \mathrm{N}$ & $136^{\circ} 38.2103^{\prime} \mathrm{E}$ & 1937.50 & 11 & 86.5 & 60.29 & 69.7 & $0-286.5$ & 286.5 & 3 \\
\hline \multirow[t]{2}{*}{$\mathrm{C} 0002 \mathrm{~L}$} & $33^{\circ} 17.9970^{\prime} \mathrm{N}$ & $136^{\circ} 38.2200^{\prime} \mathrm{E}$ & 1937.50 & 24 & 228.0 & 186.4 & 81.8 & $0-505.0$ & 505.0 & 3 \\
\hline & & \multirow{2}{*}{\multicolumn{2}{|c|}{$\begin{array}{c}\text { Site C0002 totals: } \\
136^{\circ} 55.0351^{\prime} \mathrm{E} 3509.50\end{array}$}} & 44 & 371.5 & 272.79 & 73.4 & $0-2005.5$ & 6217.5 & 80 \\
\hline \multirow[t]{2}{*}{$\mathrm{C} 0012 \mathrm{H}$} & $32^{\circ} 44.8783^{\prime} \mathrm{N}$ & & & 0 & LWD/MWD & - & - & $0-710.0$ & 710.0 & 6 \\
\hline & & \multirow{2}{*}{\multicolumn{2}{|c|}{$\begin{array}{l}\text { Site C0012 totals: } \\
136^{\circ} 40.8826^{\prime} \text { E } 3084.5\end{array}$}} & 0 & - & - & - & $0-710.0$ & 710.0 & 6 \\
\hline \multirow[t]{2}{*}{ C0018B } & $33^{\circ} 09.4319^{\prime} \mathrm{N}$ & & & 0 & LWD/MWD & - & - & $0-350$ & 350.0 & 1.5 \\
\hline & & \multicolumn{2}{|c|}{ Site C0018 totals: } & 0 & - & - & - & $0-350$ & 350.0 & 1.5 \\
\hline C0021A & $33^{\circ} 10.0482^{\prime} \mathrm{N}$ & \multirow{2}{*}{\multicolumn{2}{|c|}{$\begin{array}{c}136^{\circ} 39.4854^{\prime} \text { E } 2940.50 \\
136^{\circ} 39.8610^{\prime} \text { E } 2944.00\end{array}$}} & 0 & LWD/MWD & - & - & $0-294.0$ & 294.0 & 1 \\
\hline $\mathrm{C} 0021 \mathrm{~B}$ & $33^{\circ} 10.0555^{\prime} \mathrm{N}$ & & & 14 & 120.4 & 129.91 & 107.90 & $0-194.5$ & 194.5 & 4 \\
\hline \multirow{5}{*}{$\begin{array}{l}\mathrm{C} 0022 \mathrm{~A} \\
\mathrm{C} 0022 \mathrm{~B}\end{array}$} & & \multicolumn{2}{|c|}{ Site C0021 totals: } & 14 & 120.4 & 129.91 & 107.90 & $0-294.0$ & 488.5 & 5 \\
\hline & $33^{\circ} 13.0680^{\prime} \mathrm{N}$ & \multirow{2}{*}{\multicolumn{2}{|c|}{$\begin{array}{l}136^{\circ} 43.4540^{\prime} \text { E } 2675.50 \\
136^{\circ} 43.4667^{\prime} \text { E } 2674.00\end{array}$}} & 0 & LWD/MWD & - & - & $0-420.5$ & 420.5 & 3 \\
\hline & $33^{\circ} 13.0833^{\prime} \mathrm{N}$ & $136^{\circ} 43.4667$ & & 41 & 345.0 & 305.5 & 88.6 & $0-419.5$ & 419.5 & 6.5 \\
\hline & & \multicolumn{2}{|c|}{ Site C0022 totals: } & 41 & 345.0 & 305.5 & 88.6 & $0-420.5$ & 840.0 & 9.5 \\
\hline & & \multicolumn{2}{|c|}{ Expedition 338 totals: } & 198 & 836.9 & 708.2 & 84.6 & & 8606.0 & 102 \\
\hline
\end{tabular}

LWD = logging while drilling, MWD = measurement while drilling. $-=$ not applicable.

concentration interval of $1500-1550 \mathrm{~m}$ b.s.f. and a fault identified at $1638 \mathrm{~m}$ b.s.f. on LWD resistivity images.

Salinity, chlorinity, and sodium in interstitial water show similar changes with depth, reaching minimum concentrations at 300-500 mb.s.f. (Fig. 7). These minimum concentrations are attributable to freshwater derived from the dissociation of methane hydrate.

Methane in headspace gas shows a relatively high concentration at $\sim 300 \mathrm{~m}$ b.s.f., and propane shows high concentration from 200 to $400 \mathrm{~m}$ b.s.f. (Fig. 7). The methane- and propane-rich interval (200-400 m b.s.f.) corresponds to the gas hydrate zone inferred from resistivity and sonic log data (Expedition 314 Scientists, 2009). No massive gas hydrates were found in cores from this interval, although gas-rich sands were common. This suggests disseminated methane hydrate. A methane peak was observed in mud gas data at the Unit III/IV boundary.

The ratio of methane to ethane plus propane $\left(\mathrm{C}_{1} /\left[\mathrm{C}_{2}+\right.\right.$ $\left.\left.\mathrm{C}_{3}\right]\right)$ and $\delta^{13} \mathrm{C}$ concentration in methane $\left(\delta^{13} \mathrm{C}-\mathrm{CH}_{4}\right)$ suggest that the methane in the gas hydrate zone is mostly of microbial origin (Strasser et al., 2014a). The $\mathrm{C}_{1} /\left(\mathrm{C}_{2}+\mathrm{C}_{3}\right)$ and $\delta^{13} \mathrm{C}-\mathrm{CH}_{4}$ data of mud gas sampled during riser drilling in Hole $\mathrm{C} 0002 \mathrm{~F}$ show that thermogenic methane gradually increases with depth up to $\sim 50 \%$ at $\sim 2000$ m b.s.f.

Discrete moisture and density (MAD) data on cuttings (below $875.5 \mathrm{~m}$ b.s.f. in Hole C0002F) show lower bulk density and higher porosity compared with measurements on discrete samples from cores, as observed during previous riser drilling (Expedition 319 Scientists, 2010; Inagaki et al., 2012). Analyses of Expedition 338 cuttings revealed that these differences resulted from mixing of aggregates produced during the drilling process, termed drilling-induced cohesive aggregates.

Compressional borehole breakouts and drilling-induced tensile fractures (DITFs) observed in Hole C0002F suggest a northeast-southwest orientation of the maximum horizontal stress $\left(\sigma_{H_{\max }}\right)$, which is consistent with breakout data obtained in Hole C0002A (Expedition 314 Scientists, 2009). A leak-off test (LOT) performed at $875.5 \mathrm{~m}$ b.s.f. yielded an estimate of $32 \mathrm{MPa}$ as the least horizontal principal stress $\left(\sigma_{H_{\min }}\right)$, which is consistent with a LOT performed at 703.9 m b.s.f. in Hole C0009A (Expedition 319 Scientists, 2010).

\subsection{Sites C0018, C0021 and C0022 in the outer wedge}

LWD logs (holes C0018B and C0021A) and cores (Hole C0021B) were collected to characterize MTDs in the slope basin seaward of the megasplay fault zone. New logging data are used to define two logging units in Hole C0018B (Fig. 8) and three subunits in Hole C0021 A logs (Fig. 9), which correlate to subunits defined based on visual core descriptions and X-ray CT images in Hole C0021B (Fig. 9) and at Site C0018 (Expedition 333 Scientists, 2012a). 

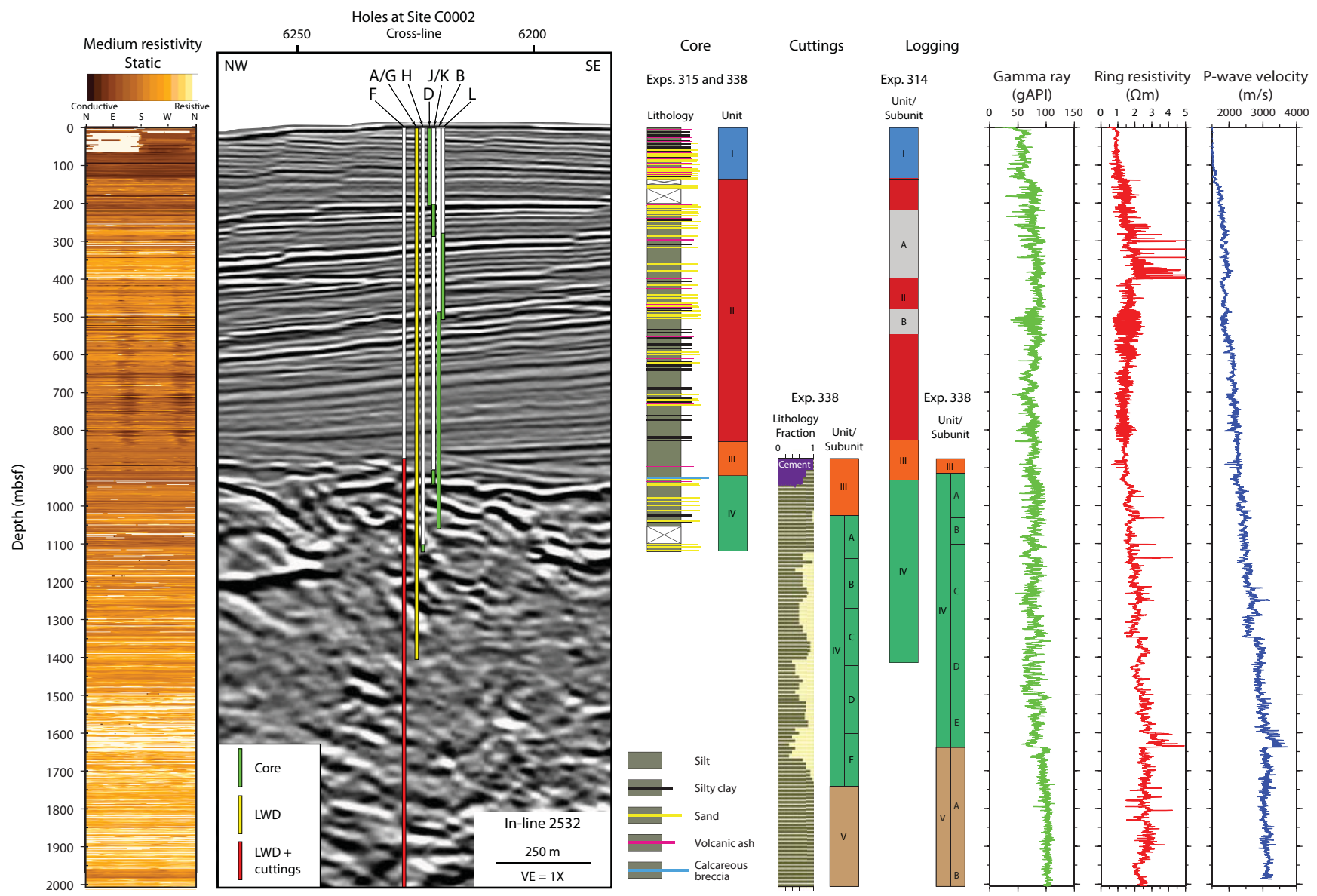

Figure 6. Cuttings-core-log-seismic integration at Site C0002: composite medium button static resistivity, In-line 2532 seismic data (Kumano 3-D PSDM volume; Moore et al., 2009), composite core lithology and units, cuttings lithology and units, logging units from holes C0002A and $\mathrm{C} 0002 \mathrm{~F}$, and composite logging-while-drilling (LWD) data. In logging unit panel (Exp. 314), gray interval A indicates possible gashydrate zone, and interval B indicates possible area with small amounts of free gas (after Expedition 314 Scientists, 2009).

\subsubsection{Site C0018}

Six MTDs (1-6) were identified in cores from Hole C0018A (Expedition 333 Scientists, 2012a); however, the lower resolution of the LWD data allowed interpretation of only two MTD intervals in Hole C0018B by resistivity image analysis. The tadpole diagram (bedding dip angle in Fig. 8) shows the high-angle, randomly oriented bedding (Fig. 8). Logging MTD B corresponds to lithologic MTD 6 in cores from Hole C0018A, while the depth range of logging MTD A encompasses lithologic MTDs 3-5 of Hole C0018A (Fig. 8).

\subsubsection{Site C0021}

Lithologic Unit IA is composed of mottled silty clay with rare thin interbeds of fine sand and ash layers. Lithologic Unit IB is composed of a succession of thin sand beds interbedded with silty clay and occasional ash layers (Fig. 9). Unit IA also contains two intervals of MTD with chaotic and distorted bedding, i.e., MTD A and MTD B (Fig. 9).
The top of MTDs A and B are defined by a zone of mud clasts capped by a thin draping sand. Below the mud clasts, a zone of chaotic/tilted/homogenous bedding occurs. The base of the MTDs is defined as the last occurrence of a shear zone, which also corresponds to the base of a zone with relatively high shear strength. We note that MTD A identified in Hole C0021B and the upper zone with chaotic bedding observed in Hole C0021A do not have the same characteristics as MTD A identified from structural analysis of the resistivity image data in Hole C0018B (Strasser et al., 2014b), which was postulated to correspond to several of the smaller MTDs observed in Hole C0018A cores (Strasser et al., 2014b; Expedition 333 Scientists, 2012a). The mismatch between the upper sections of these two sites is corroborated by the seismic data (Fig. 4), which show that the package of low reflectivity at the corresponding depth at Site C0021 is truncated to the southeast and does not extend to Site C0018.

A prominent regional seismic reflection (Kimura et al., 2011; Strasser et al., 2011) marks the top of the thickest MTD 

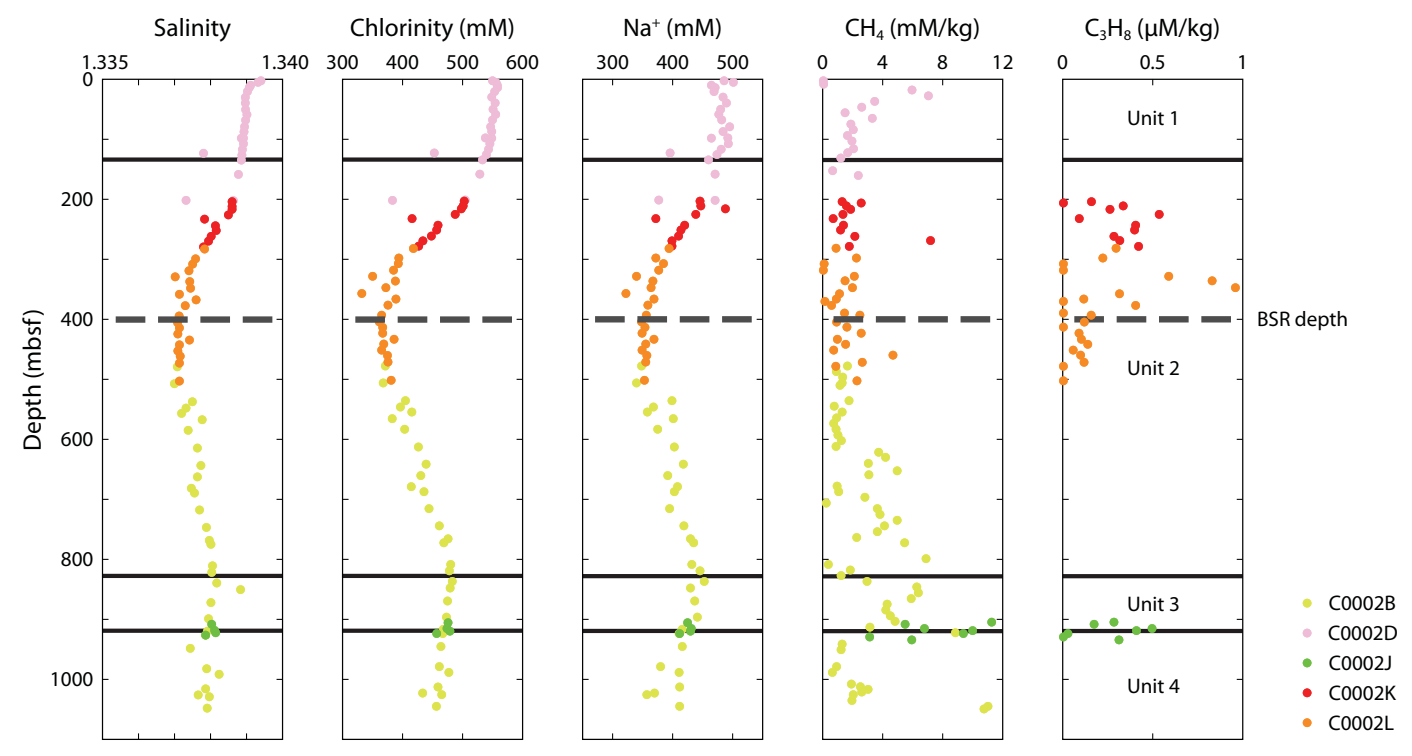

Figure 7. Profiles of salinity, chlorinity, and $\mathrm{Na}^{+}$in interstitial water, and those of methane and propane in headspace gas at Site C0002. Gray dashed line indicates level of BSR for reference. Lithologic unit boundaries are from core interpretations (after Expedition 315 Scientists, 2009; Strasser et al., 2014a).

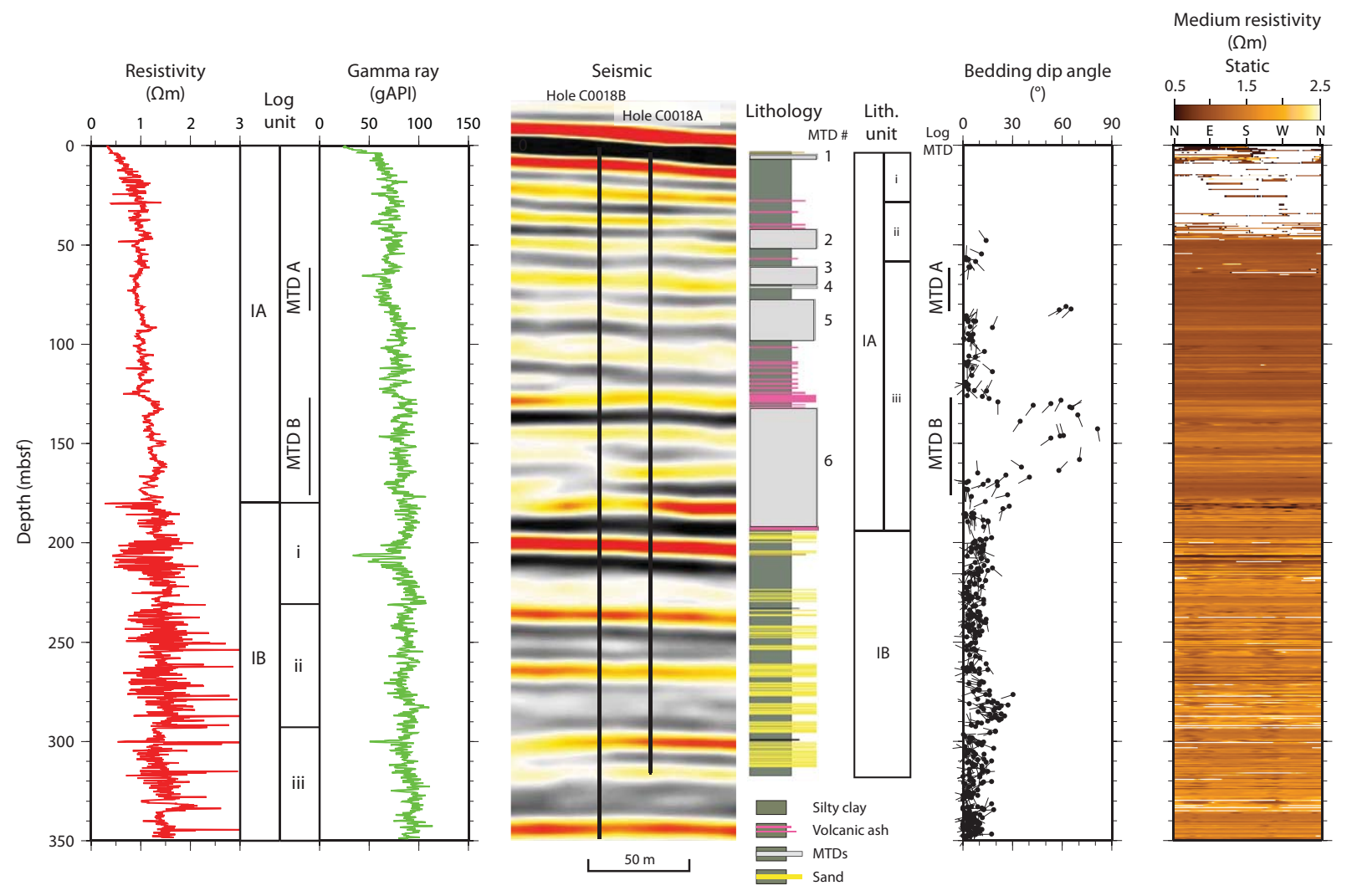

Figure 8. Core-log-seismic integration at Site C0018: LWD data, lithology with mass transport deposit (MTD) intervals and lithologic units, seismic data from In-line 2315 (Kumano 3-D PSDM volume; Moore et al., 2009), bedding dips, and medium button static resistivity. 

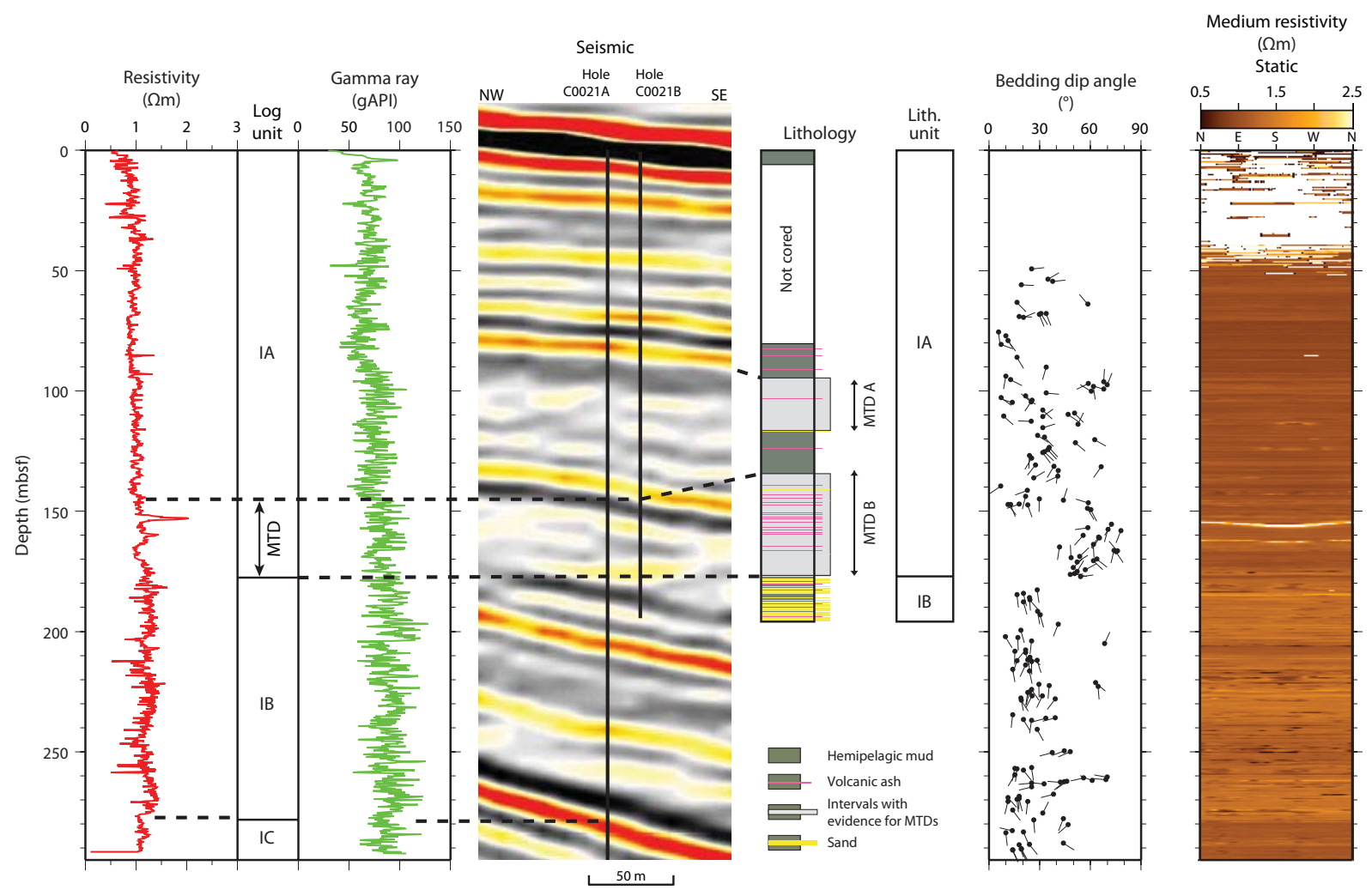

Figure 9. Core-log-seismic integration at Site C0021: LWD data, lithology with mass transport deposit (MTD) intervals and lithologic units, seismic data from In-line 2270 (Kumano 3-D PSDM volume; Moore et al., 2009), bedding dips, and medium button static resistivity.

(Fig. 4), which represents MTD 6 and MTD B at sites C0018 and C0021, respectively (Figs. 8, 9).

\subsubsection{Site C0022}

LWD data and cores were collected at Site C0022 to characterize the uppermost $400 \mathrm{~m}$ of sediment near the tip of the megasplay fault zone where the seaward-most branch of this fault system approaches the surface (Figs. 2, 5; Moore et al., 2007, 2009).

Two lithologic subunits are recognized in Hole C0022B. Subunit designations are adopted with minor modification from Site C0008 (Expedition 316 Scientists, 2009). Subunit IA is dominated by silty clay with a variable component of calcareous nannofossils, foraminifers, siliceous biogenic debris, and volcanic ash (Fig. 10). Subunit IB consists of a series of interbedded mud clast gravels with thin sand, clayey silt, and silty clay in the upper part and is dominated by silty clay in the lower part (Fig. 10). This mud clast gravel is correlative with a similar section at $\sim 245-270$ m b.s.f. in lithologic Subunit IB of Hole C0008A (Expedition 316 Scientists, 2009).

Bedding is subhorizontal with dip angles $<15^{\circ}$ throughout the entire section, except in the vicinity of the possible splay fault.
The interval of 100-101 m b.s.f. (delineated by gray line, Fig. 10) is a plausible candidate for the location of the splay fault at Site C0022, because of: (1) increased bedding dip with systematic orientation; (2) more minor faults $20 \mathrm{~m}$ above this interval; (3) poor core recovery; and (4) three $2 \mathrm{~cm}$-thick intervals of claystone showing planar fabrics not encountered elsewhere in Hole C0022B.

A high-resistivity (up to $\sim 1.5 \Omega \mathrm{m}$ ) interval at $85-$ $88 \mathrm{~m}$ b.s.f., a low-resistivity $(0.72 \Omega \mathrm{m})$ spike at $100 \mathrm{~m}$ b.s.f., and a high-resistivity (up to $\sim 1.7 \Omega \mathrm{m}$ ) interval at 102 $106 \mathrm{~m}$ b.s.f. correspond to a highly fractured zone and are likely related to the megasplay faulting (Fig. 10).

Interstitial water data in Hole C0022B are similar to those in holes C0004D, C0008A, and C0008D. However, the depth profiles of $\mathrm{pH}$, chlorinity, $\mathrm{Na}^{+}, \mathrm{Ca}^{2+}, \mathrm{Fe}^{2+}, \mathrm{Li}^{+}$and $\mathrm{Rb}^{+}$ change at $\sim 100 \mathrm{~m}$ b.s.f., perhaps associated with the megasplay fault.

MAD measurements show that porosity decreases from $70 \%$ at the seafloor to $45-50 \%$ at $\sim 100 \mathrm{~m}$ b.s.f. and then increases to $60 \%$ at $150 \mathrm{~m}$ b.s.f. The minimum porosity occurs at $93.4-94.7 \mathrm{~m}$ b.s.f., which is close to the proposed location of the megasplay fault. 

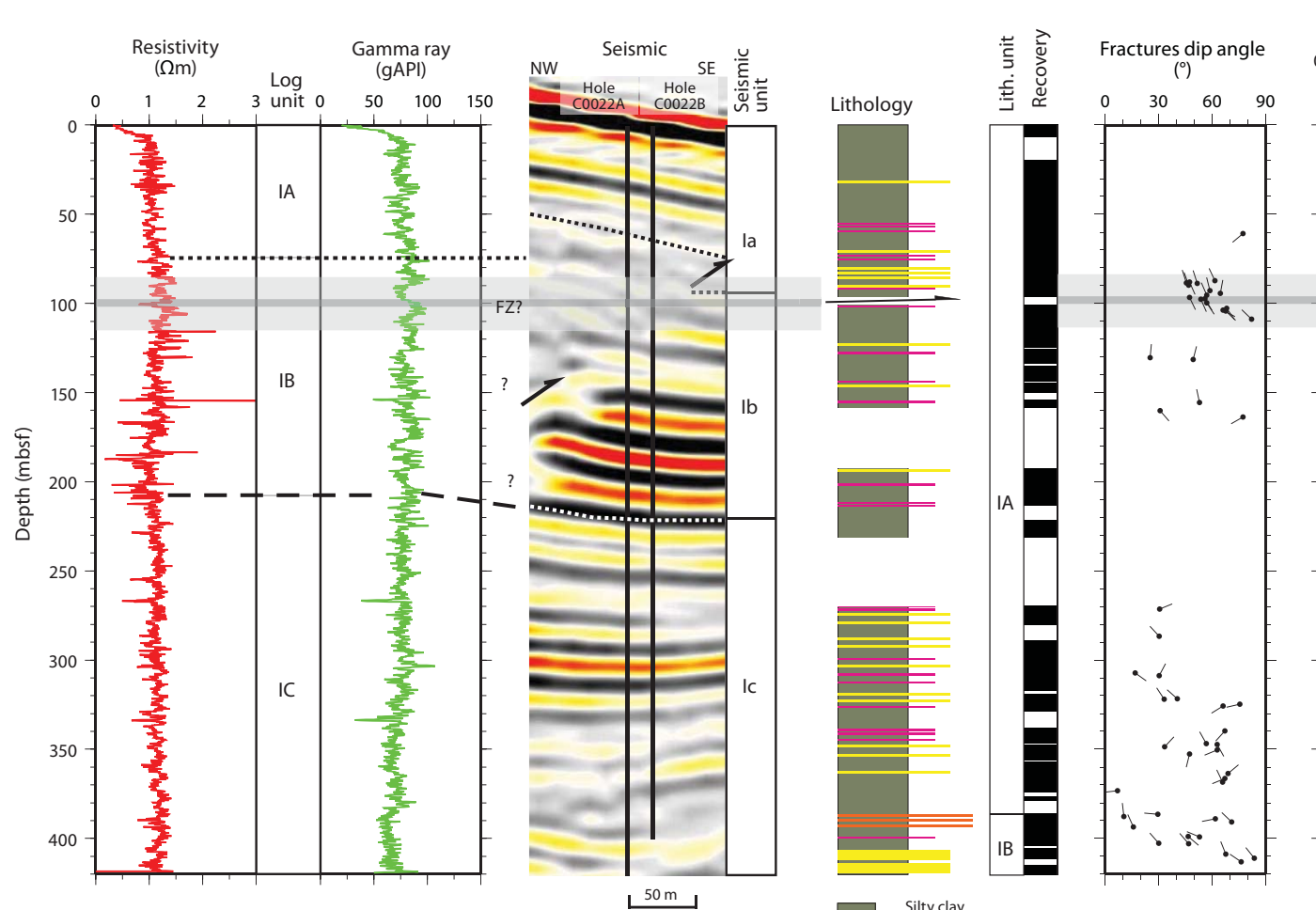

Medium resistivity $(\Omega m)$
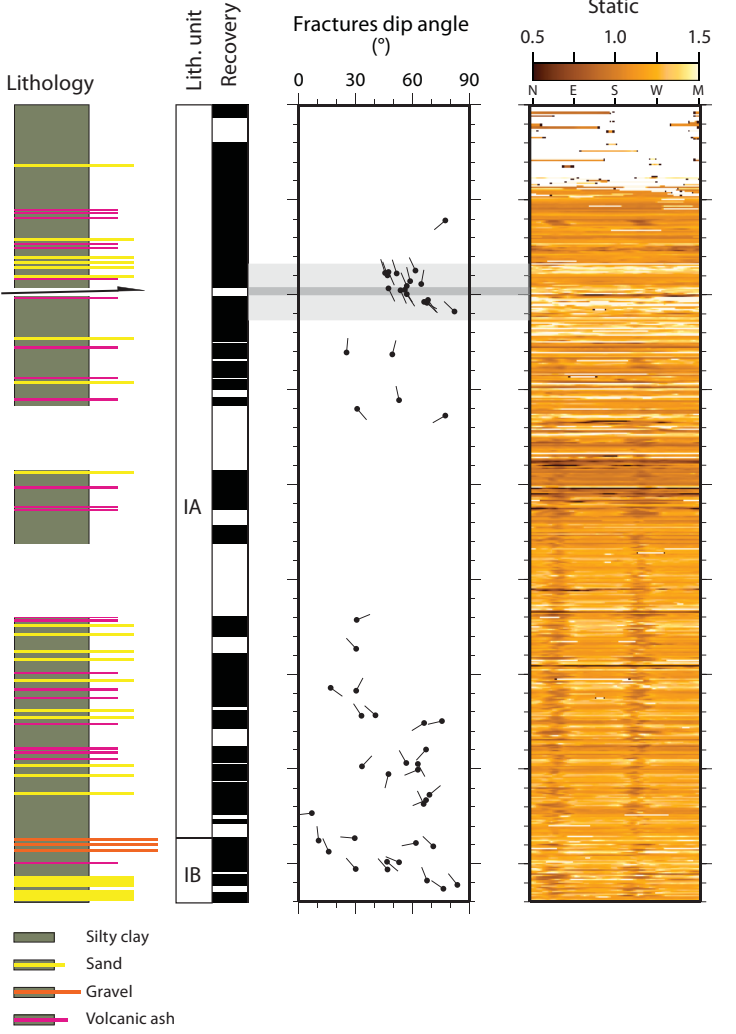

Figure 10. Core-log-seismic integration at Site C0022: LWD data and seismic data from In-line 2315 (Kumano 3-D PSDM volume; Moore et al., 2009) with seismic units defined by Kimura et al. (2011), lithology and lithologic units, fracture dips, and medium button static resistivity. Dashed and dotted black lines show correlations ("?" = tentative) between the different data sets. Shaded box highlights tip of the splay fault zone (FZ) and wider deformation zone, identified from fractures in resistivity images and shear zones in cores.

\subsection{Site C0012 on Kashinosaki Knoll}

LWD data in Hole C0012H (0 to 709.0 m b.s.f.) can be combined with core analyses from previous expeditions (Expedition 322 Scientists, 2010; Expedition 333 Scientists, 2012b) and seismic data (Park et al., 2008) to characterize the subduction zone inputs.

Based on variations of the gamma ray data, eight logging units were identified: six (I-VI) within the sedimentary cover and two (VII and VIII) within the basement, which are mostly comparable to lithologic units identified by Expedition 322 Scientists (2010) and Expedition 333 Scientists (2012b) (Fig. 11). Logging units IV, VI and VII were further divided into subunits based on resistivity and sonic velocity.

Logging Unit VII (530.3-626.6 m b.s.f.) represents the uppermost part of the oceanic basement, and corresponds to lithologic Unit VII and seismic Unit G (Fig. 11). Through logging Unit VII, the resistivity, $P$ wave velocity and gamma ray logs exhibit significant variations, with jumps to high resistivity and gamma ray values in subunit VIIB (Fig. 11), possibly reflecting variable sediment volume within the basement or variable alteration of the basalt.
Logging Unit VIII (626.6-709 m b.s.f.) is characterized by low gamma ray values with minor fluctuations, high resistivity values and $P$ wave velocities of $\sim 4-5 \mathrm{~km} \mathrm{~s}^{-1}$, suggesting the presence of uniform or fresh basalt (Fig. 11).

\section{Summary}

Riser drilling was conducted in Hole C0002F to $2005.5 \mathrm{~m}$ b.s.f. and suspended for future reoccupation and completion of the NanTroSEIZE project. LWD data, mud-gas analyses, and cuttings samples in Hole C0002F provided constraints on lithology, structure, physical properties, and geochemistry of the previously unaccessed deeper part of the Nankai accretionary prism. Riserless coring in holes $\mathrm{C} 0002 \mathrm{H}, \mathrm{C} 0002 \mathrm{~J}, \mathrm{C} 0002 \mathrm{~K}$, and $\mathrm{C} 0002 \mathrm{~L}$ provided core samples (1) across the previously unsampled gas hydrate zone of the Kumano forearc basin; (2) across the Kumano forearc basin - accretionary prism unconformity, and (3) in the uppermost accretionary prism. Thus, these operations enabled not only exploration of the accretionary prism to $\sim 2005 \mathrm{~m}$ b.s.f., but also complemented current knowledge of Site C0002. 


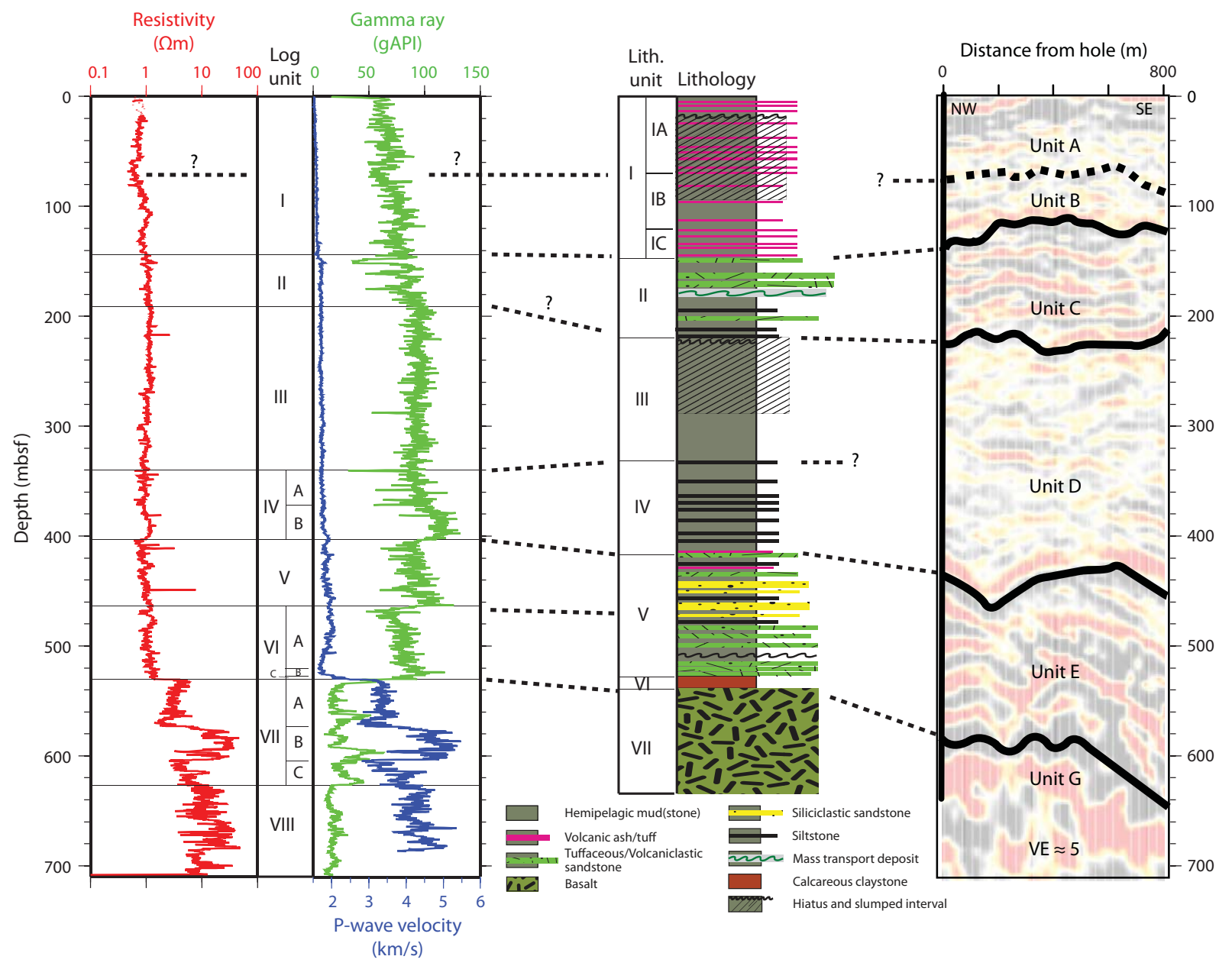

Figure 11. Core-log-seismic integration at Site C0012: LWD data from Hole C0012H with unit boundaries, composite lithologic column (holes C0012A-C0012G; Expedition 333 Scientists, 2012b), and seismic data from In-line 95 (IFREE 3-D PSDM volume; Park et al., 2008) showing the interpretation of Expedition 322 Scientists (2010). Black dashed lines = correlations ("?" = tentative) between unit boundaries identified for each data set. $\mathrm{VE}=$ vertical exaggeration.

LWD at sites C0012 and C0018 provided petrophysical data to complement coring from expeditions 322 and 333 . Integration of existing core and 3-D seismic data with new LWD data enabled us to characterize the petrophysical, lithological and structural manifestation of the oceanic basement and its overlying sediment at a subduction input site (Site C0012) as well as submarine landslide dynamics and MTD emplacement processes at a Nankai Trough Submarine Landslide History (NanTroSLIDE) site (Site C0018).

LWD and coring at Site C0021 provided further information on the nature, provenance, and kinematics of the MTDs observed at Site C0018 and provided data on the lateral heterogeneity of MTDs.

LWD and coring at Site C0022 provided logging data and samples across the tip of the megasplay fault, which provided additional information on the activity of the megasplay fault and its bearing on earthquakes and tsunamis.

\section{The IODP Expedition 338 Scientific Party}

Brandon Dugan (Co-Chief Scientist), Kyuichi Kanagawa (Co-Chief Scientist), Gregory Moore (Co-Chief Scientist), Michael Strasser (Co-Chief Scientist), Lena Maeda (Expedition Project Manager), Sean Toczko (Expedition Project Manager), Lionel Esteban, Olivier Fabbri, Jacob Geersen, Sebastian Hammerschmidt, Hiroki Hayashi, Katrien Heirman, Andre Huepers, Maria José Jurado Rodriguez, Koji Kameo, Toshi Kanamatsu, Yukari Kido, Hiroko Kitajima, Harue Masuda, Kitty Milliken, Ravi Mishra, Kyaw Thu Moe, Isao Motoyama, Katelyn Olcott, Kiyokazu Oohashi, Kevin T. Pickering, Sebastian Ramirez, Harunur Rashid, Yoshinori Sanada, Derek Sawyer, Anja Schleicher, Yehua Shan, Robert Skarbek, Insun Song, Toru Takeshita, Tomohiro Toki, Joanne Tudge, Susanna Webb, Dean Wilson, Hung-Yu Wu, and Asuka Yamaguchi. 
Acknowledgements. We thank the crew of D/V Chikyu and all drilling personnel who contributed to the overall success of Expedition 338. The expedition was funded by the U.S. National Science Foundation (NSF); the Japanese Ministry of Education, Culture, Sports, Science and Technology (MEXT); the European Consortium for Ocean Research Drilling (ECORD); the Ministry of Science and Technology (People's Republic of China); the Korea Institute of Geoscience and Mineral Resources; the Australian Research Council and the New Zealand Institute for Geological and Nuclear Sciences; and the Ministry of Earth Sciences (India). Thoughtful reviews by V. Toy and L. McNeill greatly improved the clarity of the manuscript.

Edited by: T. Wiersberg

Reviewed by: L. McNeill and V. Toy

\section{References}

Ando, M.: Source mechanisms and tectonic significance of historical earthquakes along the Nankai Trough, Japan, Tectonophysics, 27, 119-140, doi:10.1016/0040-1951(75)90102-X, 1975.

Baba, T., Cummins, P. R., Hori, T., and Kaneda, Y.: High precision slip distribution of the 1944 Tonankai earthquake inferred from tsunami waveforms: Possible slip on a splay fault, Tectonophysics, 426, 119-134, doi:10.1016/j.tecto.2006.02.015, 2006.

Expedition 314 Scientists: Expedition 314 Site C0002, in: Proc. IODP, 314/315/316: Washington, DC (Integrated Ocean Drilling Program Management International, Inc.), edited by: Kinoshita, M., Tobin, H., Ashi, J., Kimura, G., Lallemant, S., Screaton, E. J., Curewitz, D., Masago, H., Moe, K. T., and the Expedition 314/315/316 Scientists, doi:10.2204/iodp.proc.314315316.114.2009, 2009.

Expedition 315 Scientists: Expedition 315 Site C0002, in: Proc. IODP, 314/315/316: Washington, DC (Integrated Ocean Drilling Program Management International, Inc.), edited by: Kinoshita, M., Tobin, H., Ashi, J., Kimura, G., Lallemant, S., Screaton, E. J., Curewitz, D., Masago, H., Moe, K. T., and the Expedition 314/315/316 Scientists, doi:10.2204/iodp.proc.314315316.124.2009, 2009.

Expedition 316 Scientists: Expedition 316 Site C0008, in: Proc. IODP, 314/315/316: Washington, DC (Integrated Ocean Drilling Program Management International, Inc.), edited by: Kinoshita, M., Tobin, H., Ashi, J., Kimura, G., Lallemant, S., Screaton, E. J., Curewitz, D., Masago, H., Moe, K. T., and the Expedition 314/315/316 Scientists, doi:10.2204/iodp.proc.314315316.136.2009, 2009.

Expedition 319 Scientists: Expedition 319 summary, in: Proc. IODP, 319: Tokyo (Integrated Ocean Drilling Program Management International, Inc.), edited by: Saffer, D., McNeill, L., Byrne, T., Araki, E., Toczko, S., Eguchi, N., Takahashi, K., and the Expedition 319 Scientists, doi:10.2204/iodp.proc.319.101.2010, 2010.

Expedition 322 Scientists: Site C0012, in: Proc. IODP, 322: Tokyo (Integrated Ocean Drilling Program Management International, Inc.), edited by: Saito, S., Underwood, M. B., Kubo, Y., and the Expedition 322 Scientists, doi:10.2204/iodp.proc.322.104.2010, 2010.
Expedition 326 Scientists: NanTroSEIZE Stage 3: plate boundary deep riser: top hole engineering, IODP Prel. Rept., 326, doi:10.2204/iodp.pr.326.2011, 2011.

Expedition 333 Scientists: Expedition 333 summary, in: Proc. IODP, 333: Tokyo (Integrated Ocean Drilling Program Management International, Inc.), edited by: Henry, P., Kanamatsu, T., Moe, K., and the Expedition 333 Scientists, doi:10.2204/iodp.proc.333.101.2012, 2012a.

Expedition 333 Scientists: Site C0012, in: Proc. IODP, 333: Tokyo (Integrated Ocean Drilling Program Management International, Inc.), edited by: Henry, P., Kanamatsu, T., Moe, K., and the Expedition 333 Scientists, doi:10.2204/iodp.proc.333.105.2012, 2012b.

Heki, K.: Secular, transient and seasonal crustal movements in Japan from a dense GPS array: Implications for plate dynamics in convergent boundaries, in: The Seismogenic Zone of Subduction Thrust Faults, edited by: Dixon, T. and Moore, J. C., Columbia University Press New York, 512-539, 2007.

Henry, P., Kanamatsu, T., Moe, K., and the Expedition 333 Scientists, Proc. IODP, 333: Tokyo (Integrated Ocean Drilling Program Management International, Inc.), doi:10.2204/iodp.proc.333.2012, 2012.

Hori, T., Kato, N., Hirahara, K., Baba, T., and Kaneda, Y.: A numerical simulation of earthquake cycles along the Nankai Trough in southwest Japan: lateral variation in frictional property due to the slab geometry controls the nucleation position, Earth Planet. Sc. Lett., 228, 215-226, doi:10.1016/j.epsl.2004.09.033, 2004.

Ichinose, G. A., Thio, H. K., Somerville, P. G., Sato, T., and Ishii, T.: Rupture process of the 1944 Tonankai earthquake (Ms 8.1) from the inversion of teleseismic and regional seismograms, J. Geophys. Res., 108, 2497, doi:10.1029/2003jb002393, 2003.

Ike, T., Moore, G. F., Kuramoto, S., Park, J.-O., Kaneda, Y., and Taira, A.: Variations in sediment thickness and type along the northern Philippine Sea Plate at the Nankai Trough, Island Arc, 17, 342-357, doi:10.1111/j.1440-1738.2008.00624.x, 2008.

Inagaki, F., Hinrichs, K.-U., Kubo, Y., and the Expedition 337 Scientists: Deep coal bed biosphere off Shimokita: microbial processes and hydrocarbon system associated with deeply buried coal bed in the ocean, IODP Prel. Rept., 337, doi:10.2204/iodp.pr.337.2012, 2012.

Ito, Y. and Obara, K.: Very low frequency earthquakes within accretionary prisms are very low stress-drop earthquakes, Geophys. Res. Lett., 33, L09302, doi:10.1029/2006g1025883, 2006.

Kikuchi, M., Nakamura, M., and Yoshikawa, K.: Source rupture processes of the 1944 Tonankai earthquake and the 1945 Mikawa earthquake derived from low-gain seismograms, Earth Planets Space, 55, 159-172, 2003.

Kimura, G., Moore, G. F., Strasser, M., Screaton, E., Curewitz, D., Streiff, C., and Tobin, H.: Spatial and temporal evolution of the megasplay fault in the Nankai Trough, Geochem. Geophy. Geosy., 12, Q0A008, doi:10.1029/2010gc003335, 2011.

Kinoshita, M., Tobin, H., Ashi, J., Kimura, G., Lallemant, S., Screaton, E. J., Curewitz, D., Masago, H., Moe, K. T., and the Expedition 314/315/316 Scientists: Proc. IODP, 314/315/316: Washington, DC (Integrated Ocean Drilling Program Management International, Inc.), doi:10.2204/iodp.proc.314315316.2009, 2009.

Kopf, A., Araki, E., Toczko, S., and the Expedition 332 Scientists, Proc. IODP, 332: Tokyo (Integrated Ocean 
Drilling Program Management International, Inc.), doi:10.2204/iodp.proc.332.104.2011, 2011.

Miyazaki, S. I. and Heki, K.: Crustal velocity field of southwest Japan: Subduction and arc-arc collision, J. Geophys. Res., 106, 4305-4326, doi:10.1029/2000JB900312, 2001.

Moore, G. F., Bangs, N. L., Taira, A., Kuramoto, S., Pangborn, E., and Tobin, H. J.: Three-dimensional splay fault geometry and implications for tsunami generation, Science, 318, 1128-1131, doi:10.1126/science.1147195, 2007.

Moore, G. F., Park, J. O., Bangs, N. L., Gulick, S. P., Tobin, H. J., Nakamura, Y., Saito, S., Tsuji, T., Yoro, T., Tanaka, H., Uraki, S., Kido, Y., Sanada, Y., Kuramoto, S., and Taira, A.: Structural and seismic stratigraphic framework of the NanTroSEIZE Stage 1 transect, in: Kinoshita, M., Tobin, H., Ashi, J., Kimura, G., Lallement, S., Screaton, E.J., Curewitz, D., Masago, H., Moe, K.T., and the Expedition 314/315/316, 1-46, doi:10.2204/iodp.proc.314315316.102.2009, 2009.

Nakanishi, A., Kasahara, J., Suyehiro, K., Shimamura, H., Shiobara, H., and Hino, R.: Crustal structure around the eastern end of coseismic rupture zone of the 1944 Tonankai earthquake, Tectonophysics, 354, 257-275, doi:10.1016/S00401951(02)00342-6, 2002.

Nakanishi, A., Kodaira, S., Miura, S., Ito, A., Sato, T., Park, J.-O., Kido, Y., and Kaneda, Y.: Detailed structural image around splayfault branching in the Nankai subduction seismogenic zone: Results from a high-density ocean bottom seismic survey, J. Geophys. Res., 113, B03105, doi:10.1029/2007jb004974, 2008.

Obana, K. and Kodaira, S.: Low-frequency tremors associated with reverse faults in a shallow accretionary prism, Earth Planet. Sc. Lett., 287, 168-174, doi:10.1016/j.epsl.2009.08.005, 2009.

Ogawa, Y.: Beard-like veinlet structure as fracture cleavage in the Neogene silstone in the Miura and Boso peninsulas, central Japan, Sci. Rep. Dept. Geol., Kyushu Univ., 13, 321-327, 1980.

Park, J. O., Kaneda, Y., Tsuru, T., Kodaira, S., and Cummins, P. R.: Splay fault branching along the Nankai subduction zone, Science, 297, 1157-1160, doi:10.1126/science.1074111, 2002.

Park, J.-O., Tsuru, T., No, T., Takizawa, K., Sato, S., and Kaneda, Y.: High-resolution 3D seismic reflection survey and prestack depth imaging in the Nankai Trough off southeast Kii Peninsula, Butsuri Tansa, 61, 231-241, 2008 (in Japanese, with abstract in English).

Saffer, D., McNeill, L., Byrne, T., Araki, E., Toczko, S., Eguchi, N., Takahashi, K., and the Expedition 319 Scientists, Proc. IODP, 319: Tokyo (Integrated Ocean Drilling Program Management International, Inc.), doi:10.2204/iodp.proc.319.101.2010, 2010.
Saito, S., Underwood, M. B., Kubo, Y., and the Expedition 322 Scientists: Proc. IODP, 322: Tokyo (Integrated Ocean Drilling Program Management International, Inc.), doi:10.2204/iodp.proc.322.101.2010, 2010.

Seno, T., Stein, S., and Gripp, A. E.: A model for the motion of the Philippine Sea plate consistent with NUVEL1 and geological data, J. Geophys. Res., 98, 17941-17948, doi:10.1029/93JB00782, 1993.

Strasser, M., Moore, G. F., Kimura, G., Kopf, A. J., Underwood, M. B., Guo, J., and Screaton, E. J.: Slumping and mass transport deposition in the Nankai fore arc: Evidence from IODP drilling and 3-D reflection seismic data, Geochem. Geophy. Geosy., 12, Q0AD13, doi:10.1029/2010gc003431, 2011.

Strasser, M., Dugan, B., Kanagawa, K., Moore, G. F., Toczko, S., Maeda, L., Kido, Y., Moe, K. T., Sanada, Y., Esteban, L., Fabbri, O., Geersen, J., Hammerschmidt, S., Hayashi, H., Heirman, K., Hüpers, A., Jurado Rodriguez, M. J., Kameo, K., Kanamatsu, T., Kitajima, H., Masuda, H., Milliken, K., Mishra, R., Motoyama, I., Olcott, K., Oohashi, K., Pickering, K. T., Ramirez, S. G., Rashid, H., Sawyer, D., Schleicher, A., Shan, Y., Skarbek, R., Song, I., Takeshita, T., Toki, T., Tudge, J., Webb, S., Wilson, D. J., Wu, H.-Y., and Yamaguchi, A.: Site C0002, in: Proc. IODP, 338: Yokohama (Integrated Ocean Drilling Program), edited by: Strasser, M., Dugan, B., Kanagawa, K., Moore, G. F., Toczko, S., Maeda, L., and the Expedition 338 Scientists, doi:10.2204/iodp.proc.338.103.2014, 2014a.

Strasser, M., Dugan, B., Kanagawa, K., Moore, G.F., Toczko, S., Maeda, L., Kido, Y., Moe, K. T., Sanada, Y., Esteban, L., Fabbri, O., Geersen, J., Hammerschmidt, S., Hayashi, H., Heirman, K., Hüpers, A., Jurado Rodriguez, M. J., Kameo, K., Kanamatsu, T., Kitajima, H., Masuda, H., Milliken, K., Mishra, R., Motoyama, I., Olcott, K., Oohashi, K., Pickering, K. T., Ramirez, S. G., Rashid, H., Sawyer, D., Schleicher, A., Shan, Y., Skarbek, R., Song, I., Takeshita, T., Toki, T., Tudge, J., Webb, S., Wilson, D. J., Wu, H.-Y., and Yamaguchi, A.: Site C0018, in: Proc. IODP, 338: Yokohama (Integrated Ocean Drilling Program), edited by: Strasser, M., Dugan, B., Kanagawa, K., Moore, G. F., Toczko, S., Maeda, L., and the Expedition 338 Scientists, doi:10.2204/iodp.proc.338.105.2014, 2014b.

Tanioka, Y. and Satake, K.: Coseismic slip distribution of the 1946 Nankai earthquake and aseismic slips caused by the earthquake, Earth Planets Space, 53, 235-241, 2001.

Tobin, H. J. and Kinoshita, M.: NanTroSEIZE: the IODP Nankai Trough Seismogenic Zone Experiment, Sci. Drill., 2, doi:10.2204/iodp.sd.2.06.2006, 2006. 